Notre Dame Law School

NDLScholarship

Natural Law Forum

$1-1-1958$

\title{
A Decade of Jurisprudence in the United States of America: 1946-1956
}

Edgar Bodenheimer

Follow this and additional works at: http://scholarship.law.nd.edu/nd_naturallaw_forum Part of the Law Commons

\section{Recommended Citation}

Bodenheimer, Edgar, "A Decade of Jurisprudence in the United States of America: 1946-1956" (1958). Natural Law Forum. Paper 27. http://scholarship.law.nd.edu/nd_naturallaw_forum/27

This Article is brought to you for free and open access by NDLScholarship. It has been accepted for inclusion in Natural Law Forum by an authorized administrator of NDLScholarship. For more information, please contact lawdr@nd.edu. 


\title{
A DECADE OF JURISPRUDENGE
}

\section{IN THE UNITED STATES OF}

\author{
AMERICA : $1946-1956$
}

Edgar Bodenheimer

WhEN WE COMPARE the decade of jurisprudence in the United States which witnessed the arrival of the mid-century point with the corresponding period at the turn of the century, we are struck by the magnitude of the changes that have occurred in our basic thinking about law in this relatively short span of time. At the beginning of this century, as Roscoe Pound has shown, the temper of American jurisprudence was predominantly analytical and historical. ${ }^{1}$ The general attitude of the analytical jurist toward law has been well summarized by John Chipman Gray, who said in 1909: "The task of an analytical student of the Law is the task of classification and, included in this, of definition. It has been truly said that he who could perfectly classify the law would have a perfect knowledge of the law."2 The historical jurist, on the other hand, endeavors to find the key to the solution of legal problems not as much in the anatomical dissection of contemporary legal rules and principles as in the study of legal conceptions and institutions in the light of their historical growth and interpretation by the courts of the past. ${ }^{3}$ At the turn of the century, these two schools of thought waged valiant battles against each other; but notwithstanding their antagonism, their viewpoints are not necessarily incompatible, as an able scholar has observed. ${ }^{4}$ Although the analytical jurist was primarily interested in the rules and concepts employed by the legal system of his own day, he soon discovered that law usually stands with one foot at least in the past, and that his appointed task was by no means

1. Pound, Fifty Years of Jurisprudence, 50 Harvard Law Review 557, 558 (1937).

2. Gray, The Nature and Sources of the Law 3 (2d ed., 1921). It bears emphasis, however, that Gray, in spite of his primarily analytical approach, clearly recognized the dangers of an overrigid legal conceptualism. See, for example, his article on Some Definitions and Questions in Jurisprudence, 6 Harvard LAW Review 21, at 22-23 (1892). Furthermore, in accentuating the active and creative role played by the judiciary in the molding of law, Gray in many ways prepared the ground for the advent of legal realism in the United States.

3. Among the American works sponsoring the historical approach must be counted CARTER, Law: Its Origin, Growth and Function (1907) and Ames, Lectures on Legal History (1913).

4. Kantorowicz, Savigny and the Historical School of Law, 53 LAW QUARTERLy Review 326,334 (1937). As Kantorowicz puts it: "Both theories would be compatible, even if they were both right; they are still more compatible since they are both wrong." 
defeated if he sought enlightenment and guidance from history in pursuing his inquiries into the meaning of legal terms and concepts. There is likewise no reason why the historical jurist should consider himself estopped from engaging in analytical studies. Savigny, for instance, the founder of the historical school of law, was at the same time a past master in the logical dissection and dogmatic exposition of technical legal sources, ${ }^{\mathbf{5}}$ and there is nothing paradoxical or inexplicable in this combination of jurisprudential efforts.

While the climate of jurisprudence in the United States fifty years ago was thus dominated by the struggle as well as the cooperation between the analytical and historical schools, it has taken on a substantially different character in the decade here surveyed. With the inevitable oversimplification attendant upon every attempt at categorization, it might be stated that United States jurisprudence in the 1950's is characterized by the conflict as well as the interaction between psychological and ethical attitudes toward the law. Legal realism, which twenty years ago occupied an almost monopolistic position in American jurisprudential thought, has sought to focus its attention on judicial behavior, its psychological springs and subconscious motivations. Sociological approaches to the law have emphasized social-psychological data and community responses as formative factors in legal development. The revival of natural law ideas, on the other hand, which attained increasing momentum in the last decade, has brought in its train a renewed interest in ethics and the normative side of human conduct. Both sides in this presentday contest have flung many brickbats at each other; but just as the jurisprudential antagonists of fifty years ago complemented and supplemented each other in many significant respects, psychological and ethical theories of jurisprudence are likewise capable of close collaboration and are in fact due for an early rapprochement. A realistic appraisal of human nature, stripped of radically mechanistic and behavioristic interpretations, will necessarily yield the conclusion that man, with the most essential fibers of his existence, is an evaluating and purpose-impelled creature. Without a sense of values giving direction to his conduct and meaning to his actions, man's life becomes aimless, frustrated, and hollow. Furthermore, often in the course of his life man becomes confronted with the problem of making moral choices between alternative courses of conduct, a phenomenon which no insistence on the "deterministic" character of human behavior can explain away as a psychological reality. Psychology and ethics are, for these two reasons, closely related; it follows that a psychology which ignores the problems of normative valuation and moral conflict cannot provide us with a full and balanced

5. See Wolf, Grosse Rechtsdenker der Deutschen Geistesgeschichte 373 (1939). 
picture of the forces that shape the lives of human beings. The legal thinkers of our epoch are becoming increasingly aware of this truth, and we may confidently hope that the psychological jurists will in the future join hands with the advocates of an ethical jurisprudence in laying or renewing the foundations for an adequate legal philosophy. ${ }^{6}$

A final observation with respect to the broad currents of American jurisprudential development will conclude these introductory remarks. In 1900 it was possible to speak of an "Anglo-American jurisprudence" in the sense of an essential unity of thinking among the two chief English-speaking nations of the world in this domain of human thought. The parallelism of trends in Great Britain and the United States was sufficiently strong and conspicuous to warrant the use of the hyphenated designation. ${ }^{7}$ In contrast to this situation, a rather wide chasm has opened up between American and English legal philosophy in more recent times. The American legal realist movement has found little echo and approval in Britain; and with a few exceptions, ${ }^{8}$ the renaissance of ethical and natural law philosophy in the United States has evoked scant enthusiasm in Oxford, Cambridge, and London. English jurisprudence today is still in the grip of analytical and positivistic thinking, although it cannot be denied that some new insights have been added to the contributions of Austin, Holland, and Salmond. ${ }^{9}$ It appears justifiable under these circumstances to assert that, while jurisprudence in the United States has recently exhibited a vigorous dynamism in exploring facets of legal reality which the preceding era tended to ignore or bypass, English jurisprudence has not kept pace with the American tempo of advance and, on the whole, has remained rather stagnant. The widening of the gap has proceeded to the point where it is no longer an exaggeration to say that jurisprudence in the United States has achieved a well-nigh complete emancipation from the legal-philosophical hegemony of its erstwhile mother country.

6. This does not mean that historical or analytical studies of the law should be abandoned. See Jerome Hall's call for an "integrative jurisprudence" in INTERPRETATIONS OF MODERN Legal Philosophies 313 (ed. by P. Sayre, 1947).

7. American legal authors, such as Langdell, Gray, and Carter were, to some extent at least, the counterparts of Austin, Holland, and Maine.

8. See, for instance, Goodhart, English Law and the Moral LaW (1953); Lamont, The Principles of Moral Judgment (1946) (the author is a college principal in the British colony of Uganda); and two works of the Italian-born English scholar A. P. D'Entrèves: Natural Law (1951) and The Case for Natural Law Re-Examined, 1 Natural Law Forum 5 (1956).

9. See the useful survey by Hart, Philosophy of Law and Jurisprudence in Britain (19451952), 2 American Journal of Comparative Law 355 (1953). The recent work on Jurisprudence by Dias and Hughes (London, 1957) is strongly influenced by logical positivism and the semanticism of Ogden, Richards, Wittgenstein, and Korzybski. 
The book which reveals a stronger bond and continuity with the accustomed positivistic and analytical strain in English jurisprudence than most other recent American contributions is Edwin Patterson's Jurisprudence, the major text in the field published in the United States during the last decade. Although Patterson rejects as inadequate the view of John Austin that law is merely the aggregate of the commands issued by the state, ${ }^{10}$ his own definition of law as "a norm having the authority of the state acting in the way and within the limits prescribed by the ultimate political sovereign,"11 bears all the significant earmarks of the imperative conception of the law. The nongovernmental norms of organization, on which Eugen Ehrlich in his sociological studies of the law focused so much attention, are for Patterson outside of the ambit of the law because those who make such norms "do not have the authority to act for the state in so doing"; ${ }^{12}$ this would include corporate bylaws, rules of conduct adopted by religious bodies, collective bargaining agreements, and private agreements establishing a network of reciprocal rights and duties. While the undue restrictiveness of this view even as against the background of the modern secular state cannot be thoroughly refuted within the confines of this survey, it might be observed in passing that it would certainly be difficult to apply Patterson's notion of law either to the medieval order (where a temporal and a spiritual authority were competing for jurisdictional supremacy) or to the conditions of a primitive social organization (where a great deal of law arose more or less spontaneously and without "state action" in direct response to the social and economic needs of the group).

In other respects, Patterson's attitude towards social control by law transcends the traditional limitations of the positivistic view. Patterson is, for example, well aware of the fact that a legal system does not exhaust itself in the promulgation and enforcement of formalized rules and articulated precepts. As he aptly points out, "a body of law also contains some basic 'policies' commonly called public policies, which can scarcely be called 'rules." "13 His imperative leanings, however, again come to the forefront in his discussion of the question whether the social mores and the prevailing conceptions of morality may appropriately be regarded as sources of law. Patterson maintains that

10. Patterson, Jurisprudence: Men and Ideas of the Law 126 (1953).

11. Id. at 159. See also Patterson, My Philosophy of Law 233 (1941): "Law is the aggregate of interrelated rules and principles of human conduct which are prescribed by the government (state) and are potentially enforceable by it to the limit of its power."

12. Op. cit. supra, note 10 at 172 .

13. Id. at 125 . 
such principles may be adopted as grounds for a judicial decision only if an authoritative norm of the positive law (such as the well-known provision of the Naturalization Act requiring "good moral character" as a prerequisite to the acquisition of citizenship) permits recourse to such nonlegal precepts. ${ }^{14}$ $\mathrm{He}$ is willing to concede, however, that moral standards and the community's conceptions of right and wrong often enter into the judicial process indirectly and unavowedly when the formal sources of the law fail to provide a solution - and the judge faces the task of filling a gap in the body of the law.15

In spite of his leaning toward statism in legal theory, it would be incorrect to classify Patterson simply as an adherent of a slightly modified Austinian creed. His philosophy of law is admittedly eclectic ${ }^{\mathbf{1 6}}$ and shows many close points of contact with the sociological and realist movements in American jurisprudence. As Hessel Yntema has observed in a perceptive review of Patterson's book, 'the author subscribes both to 'axiological realism,' envisaged in a scheme of social interests, and likewise to the imperative or formal conception of law."17 Patterson declares, for instance, that Pound's sociological theory of social interests appears to him as the best constructive philosophy of law yet devised, ${ }^{18}$ and his analysis of the judicial process in the concluding chapter of the book fits in well with many of the conclusions reached by Cardozo, Holmes, and the modern American legal realists in reference to the typical patterns of judicial behavior.

Patterson's book is written in a clear and logical style and, in addition to its exposition of the major theories of law and legal philosophy, contains many valuable observations on significant problems connected with the administration of justice. Its main defect, in the opinion of this writer, lies in the author's refusal to engage in a reasoned analysis of a most fundamental issue of jurisprudence, namely, an inquiry into the meaning of justice. Patterson does not conceal his reasons for refusing to face this issue. "Justice or injustice is primarily an emotional pull toward one side or the other," he states, "which a long-range view of legal policy may dispel."19 Furthermore, he is convinced that "neither justice, societal adaptation, nor actual observance is indispensable

14. Id. at 235-236.

15. Id. at 239.

16. Id. at 556 .

17. Yntema, Review of Patterson's Jurisprudence, 1954 Washington University Law Quarterly 111; see also the comprehensive and valuable review of Patterson's work by Fuller, American Legal Philosophy at Mid-Century, 6 Journal of Legal Education 457 (1954).

18. Op. cit. supra, note 10 at 558 .

19. Patterson, The Role of Law in Judicial Decisions, 19 Missouri LAw Review 101, 116 (1954). 
to a thing being law." 20 Because of this negative attitude towards justice, Patterson's otherwise commendable insistence on the "generality of law" as a barrier to official tyranny ${ }^{21}$ remains a more or less empty formality. A despotism of rule, enforced in a social order impregnated with the atmosphere of a house of correction, is as much a possibility in modern political reality as a despotism of whim, caprice, and individualized arbitrariness. According to Patterson, the generality of the law may lead to desirable as well as undesirable results, ${ }^{22}$ and this determinant of the law would therefore not seem to be of any particular value or benefit to society. This raises the question whether it is possible to divorce a scientific study of the law from an investigation into the institution's benefits measured in terms of the health of the social body any more than it is possible to dissociate the study of medicine from a consideration of the advantages which the human body will derive from the medical therapies. ${ }^{23}$

Patterson's ethically neutralist approach to the law shows some affinity to the general tenor and train of thought of another widely used modern textbook on jurisprudence. Inasmuch as this book was published in Britain, it would be outside the scope of this survey except for the fact that its author has recently joined the faculty of Columbia Law School. Like Patterson, Wolfgang Friedmann maintains in his Legal Theory ${ }^{24}$ that a legal order may have any conceivable content. The leading ideas implemented by its positive precepts "may be such principles as the inalienable rights of man, or the supremacy of the will of the people, or the will of the leader [italics supplied], or the duty to work for the community. ..."25 In the view of Friedmann, "no ideal of justice can be at once theoretically valid and have a specific content."26 While there is agreement between Patterson and Friedmann with respect to the complete ethical relativity of legal systems, Friedmann has in other areas of jurisprudence moved farther away than Patterson from Austinian positivism in the direction of a sociological or realist attitude toward the law.

20. Patterson, My Philosophy of Law 232 (1941).

21. Op. cit. supra, note 10 at $98,179$.

22. Id. at 98 .

23. This reviewer has set forth his own views regarding the indissoluble bonds between law and justice in a recent article entitled Law as Order and Justice, 6 Journal of Public LAW 194 (1957).

24. Friedmann, Legal Theory (3rd ed., 1953)

25. Id. at 441 .

26. Id. at 10 . 
Turning next to American legal realism, it must be noted that this movement, during the last ten years, has not been as active and aggressive in its assault upon traditional legal doctrine as was the situation in the thirties and forties of the present century. With one notable exception to be discussed later, the robust iconoclasm of realistic jurisprudence has subsided in force and intensity during the period here surveyed. Karl Llewellyn, in the 1951 edition of The Bramble Bush, corrected some extreme statements of the realist position made by him in earlier prints of the book. ${ }^{27}$ His chief contribution to jurisprudential literature in recent years consists of an article exploring certain relationships and contacts between the law and the social sciences. ${ }^{28}$ In this essay Llewellyn justly bemoans the fact that the law today is still too far removed from "any brotherly contact with the social disciplines." 29 $\mathrm{He}$ attributes the lack of adequate cooperation in part to those lawyers and jurists who continue to insist that law is made up exclusively of state-imposed norms and imperatives, but he also does not absolve the social scientists entirely from failure to make "an effective effort at neighborliness."30 $\mathrm{He}$ demonstrates convincingly that the "quantitative" side of sociology has tended to slight the legal side--a slap at the all-pervasiveness of statistics in modern sociological science which appears to be well taken. But the chief obstacle to a two-way traffic between law and the other social sciences will be eliminated, in his opinion, when the men of the law have come to realize that "there is vastly more to law than any rules." 31 As soon as we lawyers become imbued with the conviction that law is an institution, he says, consisting of going practices, relevant specialists, relevant physical equipment, and a manner of organization of the whole, and once we further perceive that this institution serves to produce and maintain "the groupness of a group" by fighting down and conquering the divergent drives, frictions, and disruptions inherent among human beings, the doors are going to be wide open for a fruitful and friendly collaboration between law and the social disciplines related to it. ${ }^{32}$

27. Llewellyn, The Bramble Bush 8-9 (1951). He states here that his earlier expression of opinion to the effect that "what [law] officials do about disputes is, to my mind, the law itself" entailed the use of "unhappy words when not more fully developed, and they are plainly at best a very partial statement of the whole truth."

28. Llewellyn, Law and the Social Sciences, Especially Sociology, 62 Harvard Law Review 1286 (1949).

29. Id. at 1286.

30. Id. at 1287 .

31. Id. at 1288 .

32. Id. at $1289,1292$. 
The tone of Llewellyn's article is one of moderation and restraint. With Llewellyn's conclusion that the rule part of the law is "one hugely developed part" of the institution, but not the whole of it, ${ }^{33}$ one may easily agree. Undoubtedly, there are many sources of a technically nonlegal character, such as mores, customs, principles of morality and justice, and prevalent social policies which exert a significant impact on the life and growth of the law.

The outstanding exception to the earlier assertion that realistic jurisprudence in the last decade has somewhat relented in its crusading vigor is found in the writings of the valiant knight-errant of American legal realism, the late Jerome Frank. In the years preceding his untimely death, Judge Frank concentrated his attention predominantly on the fact-finding process in the trial courts. He detached himself from any of the other legal realists by labelling them "rule skeptics" and pronouncing himself a "fact skeptic."34 He devoted his main scholastic energies to an analysis of the innumerable sources of error which may enter into a determination of the facts by a trial court. There may be "perjured witnesses, coached witnesses, biased witnesses, witnesses mistaken in their observation of the facts as to which they testify or in their memory of their observations, missing or dead witnesses, missing or destroyed documents, crooked lawyers, stupid lawyers, stupid jurors, prejudiced jurors, inattentive jurors, trial judges who are stupid or bigoted and biased or 'fixed' or inattentive to the testimony."35 Many of these factors, he says, and above all the impenetrable and unique personality of the judge make every lawsuit in which conflicting oral testimony is presented a highly subjective affair. According to Frank, the judge (or jury) has a "virtually uncontrolled and virtually uncontrollable fact discretion" or "sovereignty,"36 i.e., the power to choose which witnesses' stories are to be accepted as correct.

33. Id. at 1291. See also his judicious comments on the old controversy as to whether the judges make or find the law, $i d$. at 1296, and on the relationship between rule and discretion in the legal and governmental process, id. at 1296-97.

34. Frank, Courts on Trial 73-77 (1949). I agree with Edmond Cahn that fact scepticism represents the main feature of Frank's philosophy and his most original contribution to legal theory. See Cahn, Jerome Frank's Fact Scepticism and Our Future, 66 Y ALE LAw Journal 824 (1957). However, Judge Frank was a man of extremely encompassing horizons, far transcending the domain of the law, and the encyclopedic range of his interests is reflected in his numerous writings. See, among others, the following articles of his: Say It with Music, 61 Harvard Law Review 921 (1948); Words and Music, 47 Columbia Law Review 1259 (1947); Modern and Ancient Legal Pragmatism-John Dewey \& Co. vs. Aristotle, Part I, 25 Notre Dame Lawyer 207 (1950); Part II, Id. at 460 (1950); A Conflict with Oblivion: Some Observations on the Founders of Legal Pragmatism, 9 Rutgers Law Review 425 (1954).

35. Frank, Modern and Ancient Legal Pragmatism, 25 Notre Dame Lawyer 207, 254 (1950).

36. Frank, "Short of Sickness and Death": A Study of Moral Responsibility in Legal Criticism, 26 New York University Law Review 545, 584 (1951). 
While these observations have led Frank to make a number of positive and valuable proposals for trial court improvements, ${ }^{37}$ he seems to be convinced that notwithstanding such reforms a large element of irrationality, chance, and "guessiness" will always inhere in judicial fact finding, making predictability of the outcome of the lawsuits well-nigh impossible. ${ }^{38}$ Moreover, he is of the opinion that an intensive psychological self-exploration or psychoanalysis of judges, which is part of his program for reform, might free them from most of their "compulsive reactions," but at the same time render their responses less predictable than ever. ${ }^{39}$

With lower-court fact finding as the center of his legal universe, Frank takes a new look at legal rules and precedents. He admits that many rules are settled and certain and that the precedent system possesses considerable value. $40 \mathrm{He}$ is also convinced that the rules "embody important policies and moral ideals." 41 But he maintains that the objective legal norms are in many instances frustrated and nullified by the "secret, unconscious, private, idiosyncratic norms" applied in the fact finding process by trial judges or jurors. ${ }^{42}$ No rule can be the right rule, he states, if it is applied to the "wrong facts," to unreal or mistaken facts. ${ }^{43}$ "The legal rules, whether judge-made or statute-made, and the social policies the rules embody, are at the mercy of the personal subjective reactions of trial judges or juries." 44 Thus Frank concludes that the judges often play havoc with the precedent system, with the consequence that the uniformity and stability which the rules may seem to supply at first blush is frequently rendered illusory and chimerical in practice. ${ }^{45}$ A pronounced and perhaps exaggerated pessimism regarding the fallibility of human beings pervades this analysis.

Notwithstanding his skepticism concerning the reliability of trial procedures for the discovery of the truth, Frank in his writings is deeply concerned with the problem of achieving justice in the adjustment of the relations of individual parties before the court. In order to obtain justice between the parties, Frank demands an "unblindfolding of justice," 46 that is, a relaxation of the principle that justice should be administered "without respect of persons."

37. Frank, Courts on Trial 98, 100, 141-145, 183-185, 224, 248-251 (1949).

38. Id. c. III; see also op. cit. supra, note 36 at 630 .

39. Frank, op. cit. supra, note 37 at 203, 251.

40. Id. c. XIX; see also Preface to the 6th printing of Law And The Modern Mind xiii (1949).

41. Frank, op. cit. supra, note 35 at 256.

42. Frank, op. cit. supra, note 36 at 582 .

43. Frank, Courts on Trial 33 (1949).

44. Id. at 327 ; cf. also 375 .

45. Frank, op. cit. supra, note 35 at 230 ; also note 43 at 328 .

46. Frank, op. cit. supra, note 43, c. XXVIII. 
He calls for a greater individualization of cases, for a grant of wider "rule discretion" to the judges. In this way, he argues, the individualizing power which the judge possesses in any event because of his almost boundless fact discretion would be openly rather than surreptitiously exercised. It is at this point that this writer most strongly disagrees with Frank. ${ }^{47}$ Although it must be conceded that there are areas of the law and special situations in which an individualized dispensation of justice is necessary and desirable, it must also be realized that the benefits which would be derived from a rationalization and strengthening of the fact finding process, such as is advocated by Judge Frank, would to a large degree be rendered vain and ineffectual if the major guaranties for an impartial, norm-controlled, and evenhanded administration of justice were removed on a broad scale.

\section{III}

Whether or not the system of legal-political theory and method propounded by Harold Lasswell and Myres McDougal should be viewed as a branch of the American legal realist movement is open to question. The orthodox legal realist is inclined to look upon law as a body of facts and an aggregate of individual decisions determined by a multitude of personal and social factors. Lasswell and McDougal regard the law primarily as a "flow of decisions" aiming at the materialization of certain value patterns in the national or international community; the teleological element of value-realization and policyimplementation through law thereby moves into the foreground of their thinking to an extent which sets their theory apart from that of the orthodox realist. On the other hand, by deriving the value categories which are central to their system in an empirical fashion from the actual and observed desires and wants of great numbers of people, Lasswell and McDougal have selected an approach which has a great deal in common with the radical empiricism of the American legal realist. Lasswell and McDougal also agree with the legal realists in attributing considerable weight to the personality factor in decision making and to the influence which the psychologically induced predispositions of individual judges exercise in the adjudicatory process. It is therefore not accidental or surprising to find that Professor McDougal on one occasion came to the aid of American legal realism and militantly took up the cudgels on behalf of the movement against one of its most articulate critics. ${ }^{48}$

47. Cf. Bodenheimer, Review of Frank's Courts on Trial, 2 Utah LAw Review 81 (1950). 48. McDougal, Fuller $v$. The American Legal Realists; An Intervention, 50 YaLE LAW JoURNAL 827 (1941). 
The question which we posed initially should probably be answered by stating that the "policy-science" of Lasswell and McDougal, while it parts company with legal realism in many important respects, also has some deep roots in legal-realist thinking and shares with it a number of common features.

The Lasswell-McDougal value system starts from the assumption that a value is a "desired event."49 Thus, inasmuch as "men want power," powerdefined as participation in the making of important decisions-is "unmistakably a value, in the sense that it is desired (or likely to be desired)."50 Other value categories or "preferred events" gratifying the desires of men are wealth, enlightenment, well-being, respect, skill, affection, and rectitude. ${ }^{51}$ A ranking of these values in the order of their importance is held impossible by the authors since "the relative position of values varies from group to group, from person to person, and from time to time in the history of any culture or personality." 52 Nor is it regarded as feasible to assign a universally dominant role to any one particular value. What the controlling values are in a given case or situation, must in principle be determined separately in each such instance. ${ }^{53}$

Law is conceived by Lasswell and McDougal as a form of the power value and described as "the sum of the power decisions in a community." 54 It is essential to the legal process, $\mathrm{McDougal}$ says, that a formally sanctioned authority to make decisions must be conjoined with an effective control ensuring the execution of these decisions. ${ }^{55}$ This combination of formal authority and effective control produces a flow of decisions whose purpose it is to promote community values in conformity with the expectations of the community. It is one of the basic postulates of the authors that the members of the community should participate in the distribution and enjoyment of values, or, differently expressed, that it must be the aim of legal regulation and adjudication to foster the widest possible sharing of values among men. The ultimate goal of legal control, as envisaged by Lasswell and McDougal, is a world community in which a democratic distribution of values is encouraged and promoted, in which all available resources are utilized to the maximum

49. Lasswell \& Kaplan, Power and Society 16 (1950).

50. Lasswell, Power and Personality 16 (1948).

51. Id. at 17 ; see also op. cit. supra, note 49 at 55 .

52. Op. cit. supra, note 50 at 17.

53. Op. cit. supra, note 49 at 56.

54. McDougal, The Law School of the Future: From Legal Realism to Policy Science in the World Community, 56 Y YLE LaW Journal 1345, 1348 (1947); McDougal, The Role of Law in World Politics, 20 Mississippi Law Journal 253, 262 (1949).

55. McDougal, Law as a Process of Decision: A Policy-Oriented Approach to Legal Study, 1 Natural Law Forum 53, 58 (1956); McDougal, The Rule of Law in World Politics, 20 Mississippi LaW Journat, 253, 263 (1949). 
degree, and in which the protection of human dignity is regarded as a paramount objective of social policy. ${ }^{56}$

It is believed by these authors that legal science, in approaching its assigned task of fostering the democratization of values on a global scale and contributing to the creation of a free and abundant society, should minimize and deflate the role of technical legal doctrine, which is referred to as the "authoritative myth." Legal doctrines, Professor McDougal believes, have the unfortunate habit of "travelling in pairs of opposites."57 Conceptual and doctrinal antinomies are endemic to the law, and legal terms take their meaning from the context in which they are used, the person who uses them, and the objective for which they are employed. Thus, reliance on doctrine does not insure legal certainty and often defeats the attainment of socially desirable ends.

Lasswell and McDougal propose, therefore, that the technical-doctrinal approach to law, although it ought not to be entirely discarded, should be largely supplanted by a "policy" approach. Key legal terms should be interpreted in relation to the goals and vital problems of democratic living. ${ }^{58}$ Legal decisions should be viewed as "responses to precipitating events best described as value changes in social processes."59 Emphasis on definition and orientation upon rules should be replaced by "goal thinking" and functional consideration of the effect of alternative solutions upon overall community patterns. Legal doctrines should be relegated to the role of "symbols whose function it is to serve the total policies of their users."60 Sharp distinctions between law and policy, between formulations de lege lata and propositions de lege ferenda should be shunned.61 "Every application of general rules," says McDougal, "customary or conventional or however derived, to specific cases in fact requires the making of policy choices." 62 While the adjudicating organs may seek guidance from past judicial experience, they should always

56. See, for instance, McDougal, Law as a Process of Decision: A Policy-Oriented Approach to Legal Study, 1 Natural Law Forum 53, 67, 72 (1956); Lasswell and McDougal, Legal Education and Public Policy: Professional Training in the Public Interest, 52 Yale Law Journal 203, 212 (1943).

57. McDougal, The Role of Law in World Politics, 20 Mississippi Law Journal 253, 260 (1949).

58. Lasswell and McDougal, Legal Education and Public Policy: Professional Training in the Public Interest, 52 Yale Law Journal 203, 216 (1943).

59. McDougal, Law as a Process of Decision: A Policy-Oriented Approach to Legal Study, 1 Natural Law Forum 53, 65 (1956).

60. McDougal, op. cit. supra, note 57 at 267.

61. McDougal, International Law, Power, and Policy: A Contemporary Conception, 82 RecueIl DEs Cours 137, 144 (Hague Academy of International Law, 1953).

62. Id. at 155 . 
focus their vision strongly upon the probable impact of the decision upon the future of their community ${ }^{63}$ Thus, according to McDougal, the question which the judges at the Nuremberg trial should have asked themselves in the first place was this: Will the judicial trial of the Nazi conspirators do more to promote security in the future than their summary execution or their being allowed to go free? In other words, will such a trial do more than any other practical alternative to promote the values that we all have at stake? Such an approach is regarded by McDougal as far superior to some "mechanical manipulation" of traditional doctrines of ex post facto punishment. ${ }^{64}$

A system of legal thought and method as ambitious as that devised by Lasswell and McDougal cannot be appraised thoroughly and in detail within the confines of a survey article. However, because of the influence which this scheme has exerted on legal thinking in recent years, this writer wishes to raise a few questions with respect to it which may furnish the basis for further discussion and argument.

1) According to Lasswell and McDougal, the touchstone of whether or not a certain "preferred event" constitutes a value is whether or not the event is one that is normally desired or longed for by people. Thus, since people like to be rich rather than poor, it follows that wealth must find a secure place in a system of values. This leaves open the question whether, from the standpoint of an objective philosophy of values, a distinction should not be made between (a) desires that are rooted in purely self-centered and perhaps irrational promptings of the human psyche and (b) human aspirations whose satisfaction contributes to the sum total of social good. A frustrated individual may crave for power in order to compensate for a low estimate of his self, and he may exercise such power, if attained, in a tyrannical and oppressive manner. Although power wielded in the hands of great and constructive personalities may sometimes have the distinct attributes of a positive value, it appears highly doubtful whether power as such should be included in a scheme of values without substantial explanations and qualifications. As Jerome Hall has observed, "power, unqualified and unspecified, is one of the vaguest notions in the history of human thought." 65 It is realized that the objection is one that addresses itself chiefly to a terminology which equates "value" with an event that gratifies desire. As far as the substance of their system is concerned, the authors will insist that their postulate of a wide

63. McDougal, Law and Power, 46 American Journal of International Law 102, 110 (1952).

64. McDougal, op. cit. supra, note 57 at 267.

65. Hall, Unification of Political and Legal Theory, 69 Political ScIence Quarterly 15, 17 (1954). 
sharing of power among the members of the community would necessarily minimize the danger of abuse.

It might also be noted that certain values which would seem to be of special relevance for the institution of law are omitted or at least not specifically named in the Lasswell-McDougal system. These are freedom, security, and justice. Perhaps the authors would contend that a proper diffusion of the other values in the social order would firmly guarantee these three. Furthermore, it might be possible to subsume at least the notion of justice under the category of "rectitude," which is recognized by the authors; but this would result in the inclusion of all moral values of an individual as well as social character under this broad term and would inflate the concept to unmanageable dimensions.

2) It would seem to this reviewer that the scope and intensity of "normative ambiguity," which in the opinion of Lasswell and McDougal pervades our own and every other legal system, is overemphasized by these authors. In presenting examples of principles that "travel in pairs of opposites" from the area of international law, McDougal pits the doctrine of pacta sunt servanda against the doctrine of rebus sic stantibus, sovereignty against world order, aggressive war against self-defense, reprisals against proportionality, freedom of the seas against contiguous zones. ${ }^{66}$ In theory, these juxtapositions do not represent pure antitheses or pairs of opposites which are mutually exclusive, but designate principles that in some important respects complement each other. Thus, the notion of pacta sunt servanda reaches the ends of its bounds at the point where the doctrine of rebus sic stantibus may justifiably claim application, and the doctrine of freedom of the seas finds its limitation in the recognition of maritime belts in which the littoral state may exercise paramount rights for reasons of national defense or on other grounds. In practice, it must be conceded to McDougal that the boundary line between two principles that may come into opposition cannot always be drawn with clarity and facility, and that there may be serious disagreement as to whether a case falls within one or the other principle. These well-known twilight areas, however, do not cover the whole range of the problems that may be brought within the purview of what McDougal calls "paired opposites" (unless we are confronted with a particularly unsettled and controversial field of the law). It cannot be asserted that every breach of an international agreement can reasonably be justified under the rebus sic stantibus doctrine, or that every assertion of national sovereignty can appropriately be refuted by reference to the idea of "world order." Although the areas of uncertainty in our own

66. McDougal, op. cit. supra, note 59 at 61-62. 
legal system as well as in the domain of international law are rather farranging, there are many legal questions which, under the applicable statutory, judicial, or treaty law, can be answered with a relatively large degree of assurance.

Whatever the merits of a properly defined and delimited policy approach to law may be, the wide use of the policy concept in the solution of legal problems is unlikely to reduce the incidence of "normative ambiguity." Since the possibility of a ranking of the values which the legal order should recognize and promote is denied by Lasswell and $\mathrm{McD}$ ougal, little guidance is provided by their system to a judge who is confronted with a case in which the values of rectitude and wealth, or of enlightenment and power, happen to be in conflict with each other. If predictability of decision is in itself a value of the legal order-and this is by no means denied by the two authorsa pure policy approach with a minimum of normative-technical assistance to the judge would materially increase the uncertainty of legal decisions. If, on the other hand, clashes between opposing value categories are solved by statute or authoritative interpretation, we return in part to traditional legal techniques, ${ }^{67}$ and in this event the significance of the policy notion in law would be largely confined to an insistence that legal sources should be interpreted in the light of the social purposes they are intended to serve and not by way of grammatical artifice or sterile emphasis on literalness. Such a use of the policy idea would appear to be highly meritorious.

3) A question may also be raised with respect to the contention of the authors that the dominating consideration of judges in rendering decisions should be the effect of the contemplated decision on future community policies and the future distribution of values. One should undoubtedly agree with the authors that such considerations are highly proper and desirable where the judge is confronted with the problem of deciding a novel issue of law or of determining whether a precedent should be upheld or discarded. As was pointed out above, however, McDougal would extend the notion of judicial orientation toward the future even to the criminal field, at least to international war crimes trials. Here the reservation must be made that, in appraising the future consequences of a criminal judgment, the propriety and desirability of disregarding the ex post facto principle must necessarily enter into the decision. 68 The same is, in fact, true wherever the judge has to make

67. In his Hague lecture on International Law, Power, and Policy, 82 RecueIL Des Cours 137,183 (1953), McDougal indicates that he is not opposed to a clarification of community values by "legal prescription" in order to reduce the arbitrary value preferences of individual decision makers.

68. My disagreement with Professor McDougal is not concerned with the soundness of the 
a choice between adherence or nonadherence to precedent. How sound is it, from the point of view of the future development of the law, to depart lightly from a prior decision which was relied upon by the parties to the case and presumably by many other persons? Would an incessant re-examination and revision of prior doctrine reduce the legal system to a chaotic gambling scheme unacceptable to human beings? In other words, the necessity for retrospectivity in certain types of cases may in itself be an element which a forward-looking judge may have to take into account in administering the law in a fair way.

\section{IV}

Neither the legal realists nor the advocates of a law-policy science deal directly or explicitly with a problem that in other epochs was regarded as the crucial test of the meritoriousness of a legal philosophy, viz., the problem of justice. This does not mean that the protagonists of these views are uninterested in, or oblivious of, the problem. Legal realists as well as advocates of the policy approach to law take a functional attitude toward the law; they are concerned with results rather than legal technique and they emphatically stress ends over means. In this view it is difficult to ignore the problem of justice, inasmuch as justice focuses its vision on the effects of legal rules and decisions upon human beings and human institutions. The reluctance of the two groups of legal thinkers mentioned to face the challenge of justice might perhaps find its partial explanation in an apprehension that considerations of justice are too elusive, too subjective, too dependent on intuition or mere hunch to be amenable to a scientific and rational analysis.

There are other groups of contemporary American writers in the field of legal philosophy who do not shun an open and aboveboard inquiry into the meaning and postulates of justice. The Neo-Thomists, to be dealt with later, form one group. Then there is a non-Thomist group, consisting of Edmond Cahn, Lon Fuller, Jerome Hall, and others. We shall also see that certain authors who may generally be classified as exponents of a sociological theory of law have recently turned their attention to this vital problem.

Edmond Cahn-whose philosophy of law generally is more closely related to legal realism than is that of the other authors discussed in the remainder of this paper-has expressed the conviction that the matter of justice should be approached from its negative rather than its affirmative side. Suggesting that the affirmative problem of justice has been "so beclouded by 
natural law writings that it almost inevitably brings to mind some ideal relation or static condition or set of perceptual standards,"69 Cahn prefers to place the emphasis on "the sense of injustice." Justice, under this view, is essentially a process for remedying or preventing what would arouse the sense of injustice. ${ }^{70} \mathrm{Cahn}$ points out that feelings of injustice are precipitated in a group of human beings by the creation of inequalities which the members of this group regard as arbitrary and devoid of justification. ${ }^{71}$ "The inequalities resulting from the law must make sense"; law becomes unjust when it discriminates between indistinguishables. ${ }^{72}$

The sense of injustice is seen by Cahn as a multifaceted phenomenon which includes such variegated human claims as the demand for equality, recognition of merit, respect for human dignity, conscientious adjudication of disputes, confinement of government to its proper purposes, and fulfilment of common expectations. ${ }^{73}$ The last-mentioned facet, he points out, may manifest itself in two different ways. It may assert itself, first, where normal expectations of human beings in the consistency and continuity of legal operations have been disappointed by lawmakers or judges. Any retroactive change of substantive law which reaches transactions and acts undertaken in justified reliance on the earlier law presents, therefore, a challenge to the sense of injustice. Secondly, a similarly unfavorable reaction may be produced by the opposite way of proceeding, namely, by a failure of the law to respond to new moral convictions and new social needs. Thus, the positive law may become unjust not only by breaking its promise of regularity and consistency, but likewise by violating its commitment to be sensitive to new demands of the social and economic life. Law, in order to be just, must steer a precarious and hazardous course between regularity that is uncompromising and change that is inconsiderate. The sense of injustice "warns against either standing still or leaping forward; it calls for movement in an intelligible design."74 With this view one can fully agree.

In a recent book Cahn has undertaken an inquiry into certain interrelations between law and morality, insofar as they affect the actual operations of the court processes. ${ }^{75}$ The work analyzes numerous decisions of AngloAmerican courts in which problems of a moral cast were presented to the

69. Cahn, The Sense of Injustice 13 (1949).

70. Ibid.

71. Id. at 14 .

72. Ibid.

73. Id. at 22.

74. Ibid.

75. Cahn, The Moral Decision (1955); see this writer's review of the book in 8 Journal of Legal Education 517 (1956). 
judges, and the author gives us a reasoned account of his personal reactions to these decisions.

Lon Fuller, in the decade here surveyed, contributed, among other things, a major article which, although devoted in considerable part to a review of Patterson's Jurisprudence, presents us with a valuable exposition of some important tenets of the author's own jurisprudential credo. ${ }^{76}$ Fuller levels his fire against the imperative view which sees the fundamental reality of the law in the exercise of organized force by the state; he demonstrates that without a substantial degree of acceptance of the legal order by the addressees of the law no state can in the long run maintain and enforce this order. "A theory that sets out to rest law on the power of man over man does and must default." If power is gravely abused, the foundations of voluntary acceptance upon which government and law ultimately depend are undermined.

A consideration of the minimum conditions which must be observed in order to make a legal system tolerable and workable leads Fuller into a discussion of the problem of natural law. He convincingly links natural law with the problem of "purpose" in law and shows that against the background of a teleological jurisprudence the fundamental Kantian distinction between the "is" and the "ought" loses much of its conceptual sharpness and doctrinal absoluteness. A purpose, Fuller points out, is "at once a fact and a standard for judging facts."78 If we wish to interpret and apply legal rules and principles in conformity with their essential purpose and social end, we cannot remove "oughtness" and concern for the values envisaged by the legal order from the interpretative process. Man is largely a purpose-propelled creature, and a sound philosophy of law must take into account this essential fact of human nature. Wherever men live together in society, they seek to accomplish common objectives and provide for a common need. ${ }^{79}$ Just as psychoanalysis has the function of "straightening out" the purpose-forming system called man if he is in trouble as an individual, so the law must perform the same task for man as a social being and member of a group.

76. Fuller, American Legal Philosophy at Mid-Century, 6 Journal of Legal Education 457 (1954). Other noteworthy articles by Fuller are Reason and Fiat in Case Law, 59 Harvard Law Review 376 (1946) and Freedom: A Suggested Analysis, 68 Harvard Law Review 1305 (1955).

77. Fuller, American Legal Philosophy at Mid-Century, 6 Journal of Legal Education 457,461 (1954).

78. Id. at 470 .

79. A thorough analysis of the "principle of the common need" is given in Fuller, The Problems of Jurisprudenge 694-701 (Temporary ed., 1949). This work consists of a selection of readings supplemented by comments by the editor. 
Fuller is convinced that the social order is subject to certain natural laws in the same sense in which the human psyche may be said to be governed by such laws. Because of the confusion and widespread antagonism invited by the term "natural law," Fuller recommends that a new name be used for an old phenomenon. He suggests the term "eunomics," which he defines as "the theory or study of good order and workable arrangements." $80 \mathrm{He}$ warns that eunomics must not attempt to teach any orthodoxy or doctrine of binding ultimate ends, but must see its task primarily in furnishing a doctrine of the means which the legal order must employ to attain the goals of a certain form of social organization. ${ }^{81}$ However, it may go beyond such concern for the means aspect of social ends and also demonstrate scientifically that there exist unattainable social goals for which no practicable and manageable legal forms can be devised. ${ }^{82}$ While this writer is in agreement with many of Fuller's views, the question arises whether or not the positive aims of the law, especially with reference to the present state of national and world affairs, should not be included in jurisprudential inquiry.

Jerome Hall, like Lon Fuller, emphasizes strongly that "law is more than might."83 The institution of law serves certain fundamental values of the social order, although these values are by no means static and shift appreciably with the relevant matrix of culture. ${ }^{84}$ It follows for Hall that value and social fact are closely intertwined, and that any sharp antithesis between the "is" and the "ought" flies in the face of human experience.

Hall holds that the basic values underlying the legal system must be rationally analyzed and given articulate normative expression. The administration of justice, he says, cannot be made to rest on irrational hunches, unanalyzed feelings of right or wrong, and unfettered subjective discretion. "Sound legal method depends ultimately on intelligence, factual knowledge, and a disinterested desire to discover the truth and to do what is right." 85 Hall is confident that the most significant value judgments are not merely disguised descriptions of subjective wants or personal interests. "People sometimes act against their desires," he says, "and sacrifice their interests be-

80. Id. at 477 .

81. A thoughtful criticism of this proposition is found in d'Entrèves, The Case of Natural Law Re-Examined, 1 Natural Law Forum 5, at 31-32 (1956). Professor d'Entrèves points out that "the 'best working' law is not necessarily the "best' law." Natural law, he argues, must set itself higher sights than merely to provide society with a "technology." His comments furnish a great deal of food for reflection.

82. Fuller, op. cit. supra, note 77 at 477-78.

83. Hall, Living Law of Democratic Society 8 (1949).

84. Id. at 12.

85. Id. at 53 . 
cause they decide to do the right thing. The naturalistic dogma must condemn Socrates as an idiot." 86 Under the skeptical theory of value judgments "expressions of delight when witnessing a murder would be just as rational as expressions of intense anger directed at someone who had just risked his life to rescue a drowning child." 87 The fact that it is sometimes very difficult to solve a moral problem, and that several different approaches to the solution may be equally defensible, does not, in Hall's view, justify the conclusion that objectivity in valuation is an irrational ideal. ${ }^{88}$

Hall acknowledges the enduring insights of the Stoic and medieval natural law philosophers, but proposes that in our own day the democratic ideal, epitomized in the phrase "consent of the governed," must be included in any redefinition of natural law. $89 \mathrm{He}$ expresses grave doubt as to whether "sheer power norms," devoid of ethical content and arrived at in fundamental disregard of democratic ideals, deserve to be honored with the name of "law."90

A drift towards an increasing recognition of the value problem in legal science can also be detected in the writings of some outstanding authors who in the past have been regarded chiefly as exponents of sociological theories of law. Roscoe Pound, for instance, who is looked upon as the founder of the sociological theory of law in the United States, has in recent years paid substantial attention to the moral element in law and the meaning of justice. In a book published in 1951,91 he points out that the phenomenon of justice may be viewed from two different angles. Justice may be thought of as "respect for the expectations involved in civilized life as we know it in the time and place."92 Taken in this sense, justice may serve as a positive guide and pointer in the interpretation and application of legal source materials. Over and above this, justice may also function as an absolute ideal for a society in which every human being is given a chance to live a full and equal

\footnotetext{
86. Id. at 69 .

87. Ibid.

88. Id. at 76 .

89. Id. at 85 .

90. Id. at 133 et seq. In addition to the major work discussed here, Hall's legal-philosophical ideas have found recent expression in The Challenge of Jurisprudence, 37 American Bar Association Journal 23 (1951), Concerning the Nature of Positive Law, 58 Yale LaW Journal 545 (1949), and Integrative Jurisprudence in Interpretations of Modern Legal Philosophies 313 (ed. by P. Sayre, 1947).

91. Pound, Justice According to Law (1951).

92. Id. at 6 .
} 
social and economic existence. In this second sense, justice furnishes the blueprint for a society in which ideal relations between man and man have been achieved through a wise use of the agency of law as a means of social control. ${ }^{93}$

Pound is convinced that, in striving for the attainment of a truly just society, valuations transcending subjective preferences can be reached, and that the current value skepticism must be rejected as a "give-it-up" philosophy. ${ }^{94}$ Experience tested by reason and reason tested by experience, he states, have taught us a great deal about how we must go about the task of enabling men to live together in politically organized communities with a minimum of waste, friction, and social strife. ${ }^{95}$ The ultimate goal of social organization remains for Pound the same as in his earlier writings, namely, the pragmatic ideal of a "maximum satisfaction of human wants or expectations" as propounded by William James. ${ }^{96}$

Another representative of the sociological approach, F. S. C. Northrop, has likewise evinced a strong concern for ethical valuation and the normative criteria in legal science. While Northrop assigns great significance to the sociological or "living law" norms of concrete societies which, in his opinion, the positive statutory and judicial law of these societies must reflect in order to be effective, he does not believe that the living law of a particular pattern of culture offers a final test of ethical worth and goodness. It is susceptible of being judged by a standard paramount and superior to it. This standard is a form of natural law described by Northrop as "the empirically verified philosophy of nature."97 The universal validity of the principles of this science is grounded in the fact that, although men live in different national groups and civilizations, all men in the different cultures "nevertheless live in the same nature." 98 The character of the physical universe, as described

93. A similar distinction has been suggested by Pcund in the domain of "natural law." Positive natural law is an ideal of the actual law of the time and place made to serve as a critique of that law. Natural natural law is a pure ideal of what a body of law ought to be according to some philosophical system. See Pound, Natural Natural Law and Positive Natural Law, 68 LAw Quarterly Review 330 (1952) and op. cit. supra, note 91 at 6. 94. Pound, op. cit. supra, note 91 at 22-23.

95. Id. at 29.

96. Id. at 31. Other recent writings by Pound in the field of legal philosophy include the following articles: Sources and Forms of Law: The Imperative Element, 22 Notre DAME LAWYer 1 (1946); Philosophy of Law and Comparative Law, 100 University or Pennsyluania Law Review 1 (1951); Juristic Theory in the Atomic Age, 9 Rutgers Law Review 464 (1954).

97. Northrop, Naturalistic and Cultural Foundations For a More Effective International Law, 59 Yale Law Journal 1430, 1448 (1950). See also Northrop, Ethical Relativism in the Light of Recent Legal Science, 52 Journal of Philosophy 649 (1955).

98. Northrop, Naturalistic and Cultural Foundations for a More Effective International Law, 59 Yale Law Journal 1430, 1435 (1950). 
by the sciences of mathematics and physics, and the nature of man-who is a part of this universe-yield us certain ethical and legal norms which are generally valid for all men. "Although the philosophy of a given person or people refers for its normative prescriptions to culture, it refers to physical nature and natural man for its origin and empirical verification. In other words, no philosophy is merely a specification of a living law for society; it is also at the same time an empirically originated and hence objectively verifiable theory of nature." 99

Northrop insists that the building of an effective international law to secure the survival of mankind in the future must of necessity be grounded on the scientific foundations with which this theory of natural law may provide us. ${ }^{100} \mathrm{He}$ defers this task to the future, however, since he believes that a truly universal natural law, based on the verified findings of contemporary mathematical physics and other relevant natural sciences is yet to be specified and elaborated, though the methods for determining it are already known to us. ${ }^{101}$ The "dying legal science" of positivism, with its emphasis on legal force and power politics, is inadequate in his opinion to provide us with the tools and the inspiration needed to cope with the momentous problems which the atomic age has thrust upon mankind. ${ }^{102}$

Neo-Thomist writing in the field of jurisprudence has been extremely active in the period under review. Inasmuch as the fundamental principles of the Thomistic philosophy of law-which is regarded by its votaries as a philosophia perennis-are not subject to change except in their concrete application to the specific problems of legal life, no attempt to summarize this philosophy or the contents of recent expositions of it will be made in this survey. It should be mentioned, however, that a well-written and stimulating account of this philosophy which illustrates its bearing on various practical problems of the law has recently been given to us by Dr. John Wu. ${ }^{103}$ In addition to other worthwhile features, the book attempts to bring to light certain relationships and affinities between natural law thinking and

99. Northrop, Contemporary Jurisprudence and International Law, 61 YALE LAW JourNaL 623,650 (1952).

100. Id. at 652-654. See also Northrop, The Taming of the Nations (1953).

101. Northrop, op. cit. supra, note 99 at 654 .

102. Ibid.

103. Wu, Fountain of Justice (1955). 
the methods of legal reasoning characteristic of the Anglo-American common law, at least in its classical frame.

A historical inquiry into the age-old question whether law is primarily the product of the human intellect or the human will forms the subject matter of a book by the Rev. Thomas Davitt. ${ }^{104}$ The authors dealt with in the book are for the most part medieval philosophers or theologians, among them Duns Scotus, William Ockham, Albert the Great, and St. Thomas Aquinas. An American edition of Heinrich Rommen's influential work on the natural law was published in 1948.105

Anton-Hermann Chroust, a representative of a philosophical jurisprudence which touches upon Neo-Thomism, published articles on various aspects of legal philosophy ${ }^{106}$ and also, beginning with Volume 29 of the Notre Dame Lawyer, presented a series of studies on the history of the legal profession from the time of ancient Athens. Thoughtful papers were also contributed by George Constable, ${ }^{107}$ Edward Barrett, 108 Harold McKinnon, ${ }^{109}$ Robert Wilkin, ${ }^{110}$ and Miriam Rooney. ${ }^{111}$ Prominent mention should be given to the five volumes of the University of Notre Dame Natural Law Institute, containing instructive discussions of the problem from a historical, systematic, and comparative point of view.

The survey here presented does not by any means claim completeness and full coverage of the subject. Writing in the field of jurisprudence has been so prolific in the last ten years that it is not possible to do justice to all

104. Davitt, The Nature of Law (1951).

105. Rommen, The Natural Law (transl. by T. R. Hanley, 1948).

106. Chroust, Some German Definitions of Law and Legal Philosophy from Kant to Kelsen, 22 Notre Dame LAWYer 365 (1947); Chroust, The Meaning of Law in the Common Law Tradition, 22 Notre Dame Lawyer 171 (1947); Chroust, On the Nature of Natural Law, in Interpretations of Modern Legal Philosophies 407 (ed. by P. Sayre, 1947); Chroust, The Managerial Function of Law, 34 Boston University Law Review 261 (1953); Chroust, Natural Law and Legal Positivism, 13 Ohio State Law Journal 178 (1952), reprinted in The American Jurisprudence Reader (ed. by Thomas A. Cowan, 1956).

107. Constable, Natural Law Jurisprudence and the Cleavage of Our Times, 39 Georgetown Law Journal 365 (1951); Constable, What Does Natural Law Jurisprudence Offer?, 4 Catholic University Law Review 1 (1953).

108. Barrett, Reflections on Re-Reading Frank's Law and the Modern Mind, 24 NotRE Dame LAwyer 447 (1948); Barrett, Natural Law and the Lawyer's Search for a Philosophy of Law, 4 Buffalo Law Review 1 (1954).

109. McKinnon, Law and Philosophy, 26 Canadian Bar Journal 1045 (1948); McKinnon, Natural Law and Positive Law, 23 Notre Dame Lawyer 125 (1948).

110. Wilkin, Status of Natural Law in American Jurisprudence, 24 NOTRE Dame LAWyer 343 (1949); Wilkin, Natural Law: Its Robust Revival Defies Positivists, 35 American Bar Association Journal 192 (1949).

111. Rooney, Natural Law and Legal Justice, 2 CAtholic LaWyer 131 (1955); Rooney, Law Without Justice?, 23 Notre Dame Lawyer 140 (1947). 
those who have attempted to grapple with the difficult questions of legal philosophy and legal theory. A few important publications not discussed in the preceding pages are listed in the final footnote, ${ }^{112}$ and it is regretted that these publications could not be evaluated within the confines of this essay.

The reader will agree, it is hoped, that the literature dealt with in this survey supports the analysis of the general trends of development presented in the introductory section. A reappraisal of the fundamental moral and social values served by the institution of law seems to be in the making in American jurisprudence. It is to be desired and expected that this new philosophy of values will avail itself of the recent insights into the nature and imperfections of the judicial process which the American legal realists have contributed to our science, and that it will at the same time be sensitive to the fact that without some conceptual framework and set of techniques-conceived as a means for the attainment of justice rather than an end in itselfthe administration of the law cannot secure the detachment and objectivity indispensable to its successful functioning. It must also be hoped that the legal profession will in the future utilize to the fullest extent the knowledge and information gained in other sciences with respect to the operation and laws of nature and of society. If the next decade of American jurisprudence is to be marked by an earnest collaboration between the technical lawyer, the student of the political and social scene, the natural scientist, and the ethical philosopher, this would be as much as anyone could hope for.

112. Strauss, Natural Rights and History (1953); Reuschlein, Jurisprudence: Its American Prophets (1951); Southern Methodist University Studies in JurisPRUDENCE, 4 volumes (1954-1957); Timasheff, The Sociologists Contribution to the Law, 32 Virginia Law Review 818 (1946); Cairns, Legal Theory, 9 Rutgers Law Review 388 (1954); Wild, Plato's Modern Enemies and the Theory of Natural Law (1953); Yntema, Jurisprudence and Metaphysics, 59 YALE LAw Journal 273 (1950); Yntema, Comparative Legal Research, 54 Michigan Law Review 899 (1956); Parker, Legal Positivism, 32 Notre Dame Lawyer 31 (1956); Lee, Social Values and the Philosophy of Law, 32 Virginia Law Review 802 (1946). 